\title{
Developing a postgraduate professional education framework for emergency nursing: a co-design approach
}

\author{
Karen A. Theobald ${ }^{1 *}$ (D) Fiona Maree Coyer ${ }^{1,2,3}$ (D) Amanda Jane Henderson ${ }^{4,5}$, Robyn Fox ${ }^{1,6}$, \\ Bernadette F. Thomson ${ }^{5}$ and Alexandra L. McCarthy ${ }^{7,8}$ (D)
}

\begin{abstract}
Background: Hospital and university service providers invest significant but separate resources into preparing registered nurses to work in the emergency department setting. This results in the duplication of both curricula and resource investment in the health and higher education sectors. This paper describes an evidence-based codesigned study with clinical-academic stakeholders from hospital and university settings.

Methods: The study was informed by evidence-based co-design, using emergency nursing as an exemplar. Eighteen hours of co-design workshops were completed with 21 key clinical-academic stakeholders from hospital and university settings.

Results: Outcomes were matrices synchronising professional and regulatory imperatives of postgraduate nursing coursework; mutually-shaped curriculum content, teaching approaches and assessment strategies relevant for postgraduate education; a new University-Industry Academic Integration Framework; five agreed guiding principles of postgraduate curriculum development for university-industry curriculum co-design; and a Graduate Certificate of Emergency Nursing curriculum exemplar.

Conclusion: Industry-academic service provider co-design can increase the relevance of postgraduate specialist courses in nursing, strengthening the nexus between both entities to advance learning and employability. The study developed strategies and exemplars for future use in any mutually determined academic-industry education partnership.
\end{abstract}

Keywords: Co-design, Postgraduate nursing education, Emergency nursing, Curriculum, Industry-academic, Partnership

\section{Background}

In Australia, the health industry and the tertiary sector provide post-registration courses for emergency nurses [1]. These range from practical, competency-based shorter modules to specialty programs to longer courses that are mixed theory and practice, postgraduate degrees.

\footnotetext{
* Correspondence: k.theobald@qut.edu.au

'School of Nursing, Faculty of Health, Queensland University of Technology, GPO Box 2434, Brisbane, Queensland 4000, Australia

Full list of author information is available at the end of the article
}

Irrespective of whether a course is delivered by a hospital or a university, education providers have a common goal. That is, to promote students' higher-level learning, arming them with the knowledge and skills to work from a strong evidence base [2]. To serve this end, the Australian Qualifications Framework (AQF) Council operates as an advisory body to regulate all postgraduate offerings across Australia. Despite said aims, the significant but separate energies invested by industry and universities in postgraduate

(c) The Author(s). 2021 Open Access This article is licensed under a Creative Commons Attribution 4.0 International License, which permits use, sharing, adaptation, distribution and reproduction in any medium or format, as long as you give appropriate credit to the original author(s) and the source, provide a link to the Creative Commons licence, and indicate if changes were made. The images or other third party material in this article are included in the article's Creative Commons licence, unless indicated otherwise in a credit line to the material. If material is not included in the article's Creative Commons licence and your intended use is not permitted by statutory regulation or exceeds the permitted use, you will need to obtain permission directly from the copyright holder. To view a copy of this licence, visit http://creativecommons.org/licenses/by/4.0/ The Creative Commons Public Domain Dedication waiver (http://creativecommons.org/publicdomain/zero/1.0/) applies to the data made available in this article, unless otherwise stated in a credit line to the data. 
course design and delivery often results in the unnecessary duplication of content and resources [3]. Notwithstanding the global demand for postgraduate courses, evidenced for example by 1700 United States universities offering Masters-level programs [4] and many institutions in the United Kingdom offering Graduate Certificate and Doctoral Preparation courses [5], there are critical gaps in postgraduate offerings [3] in Australia. Courses offered by higher education providers (HEP) are based on industry need and are developed and delivered with significant industry input [6]. For example, in the Australian context postgraduate courses are overseen by course advisory committees with membership comprising of academics, key industry and professional organisation stakeholders [7]. However, these advisory committees are often implemented 'after the fact' - when university stakeholders have already undertaken most of the course design and often delivered it.

This study was a collaboration of academics and educators, clinicians, postgraduate emergency nursing students, administrators and nursing regulators. The codesigned partnership offered a new way to design learning based on a culture of shared decisions, relevance and agility, created and agreed from the outset. This enabled a range of stakeholders to contribute and have their needs heard $[8,9]$. Other approaches, such as a Delphi method, would not have given us the rich engagement and ongoing feedback that we were able to achieve through the lens of the co-design approach [8].

\section{Methods}

Aim

Our aim was to be mutually involved from the beginning of course conceptualisation and design. Collectively we sought to better harness current collaborations through the development of an industry-academic postgraduate education framework that integrated the goals of both the health industry and higher education service sectors. This co-design process would ensure course credibility and relevance while maximising postgraduate students' professional learning. Importantly, inviting students, administrators and nurse regulators to work together in co-design, added new perspectives to the process.

\section{Design}

This evidence-based co-designed study involved three workshops (18 h in total) offered in June and December 2016 and May 2017. These workshops were supplemented with iterative between-workshop email and personal consultation with participants. The study was informed by the evidence-based co-design approach in which collaborative collective creativity, which recognises diverse expertise, drives the development of purposeful enterprise that seeks to optimise end-user satisfaction and enhance product and process outcomes [8]. Exemplified by Ogrin et al. [9], the human-centric collaborative approach aims to bring diverse stakeholder skills and contextual knowledge to product (in this case, curriculum) development and delivery through the development of knowledge and generation of mutuallyagreed principles [8]. Participants, including stakeholders in leadership capacities as well as product and process consumers, generate insight and are supported by key designers, researchers and leaders in establishing partnerships to effect sustainable educational change.

\section{Participants}

Purposive sampling ensured key participants were included. A total of 38 stakeholders consented with up to $55 \%$ actively participating, representing a range of invested party perspectives at each workshop. These were the Chair, National College of Emergency Nursing Australasia (CENA) Credentialing Committee, CENA Queensland President and other representatives of CENA; university-based curriculum experts, emergency nursing course coordinators and past and present postgraduate curriculum directors from the two partner universities; past and present postgraduate students of the two partner universities; emergency nursing educators and clinicians from six metropolitan hospitals in Brisbane; the Executive Directors of Nursing from Metro South and North, Directors of Nursing and Directors of Nursing Education from the partner health services; and one credentialing expert from the Office of the Chief Nursing and Midwifery Officer Queensland. Nursing experience ranged from 12 months post initial registered nurse qualification, to 45 years. Participants' professional qualifications ranged from a Bachelor degree to Doctor of Philosophy.

\section{Setting}

The study was conducted at two health services and two university settings. These settings represent two major metropolitan universities providing postgraduate nursing education courses with student enrolments across Australia and two major health services in South East Queensland providing quaternary-level emergency health care services. Emergency nursing was selected to be the focus of the study as emergency postgraduate courses were well enrolled in both university partners. Further, these settings were chosen for the existing close collaborative relationships and partners who showed the initiative to take postgraduate curriculum design to a new level.

\section{Data collection}

This study used co-design method, therefore a range of strategies during and after the workshops were used to 
generate data. The workshops were part of an iterative process with Workshop 1 informing Workshop 2, which in turn informed Workshop 3.

\section{Within the workshops}

The workshops methodically explored topics including enablers and barriers to industry-academic mutual development and delivery of postgraduate curricula; the conditions of postgraduate industry-academic engagement; compulsory content of postgraduate emergency nursing curricula across settings; and relevant teaching, learning, assessment and quality assurance approaches. Proactive partnerships were promoted in the workshops by focusing on the participants' common goals. We aimed for reciprocal and co-operative communication processes. In each workshop we used these strategies to establish a common identity as an educational 'community of practice' for postgraduate emergency nursing students - a community that aimed to negotiate a pathway for the joint development and potential delivery of a postgraduate emergency nursing course.

Consistent with evidence-based co-design approaches we explored the interface between students, regulatory bodies, universities and health services that customarily have different (but not mutually exclusive) educational goals and tend to operate under different (but not mutually exclusive) norms and performance indicators. Each workshop was led by one Chief Investigator; other Chief Investigators were embedded with participants to organise and summarise group outputs.

The first workshop, exemplified by Step 1 of the guiding principles for postgraduate curriculum transformation model (Fig. 1), established the agreed evidence for development of the University-Industry Integration Framework (Fig. 2) and envisaged a mutual understanding of the conceptual goal: "What sort of postgraduate nursing clinician do we want to produce?" In workshop two (December 2016), matrices (Tables 1 and 2) were mutually developed that described synchronisation of professional and regulatory imperatives. This included partnerships and collaborative enterprise across the health and university service sectors informed by a feasible business model that met student, industry and professional needs. In the final workshop (May 2017), the Framework (Fig. 2 ), guided by distributed leadership with mutually-

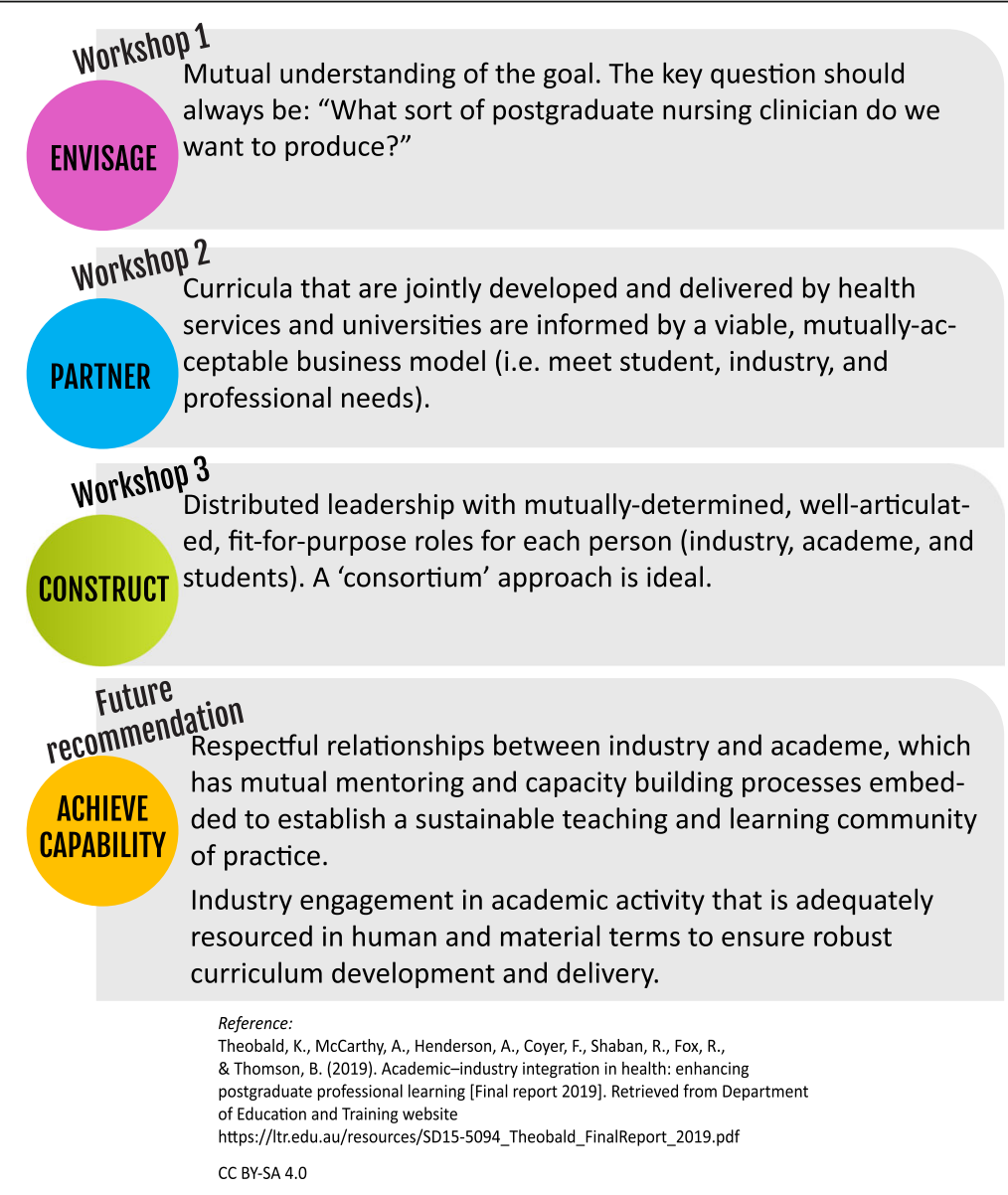

Fig. 1 Guiding principles for postgraduate curriculum transformation 


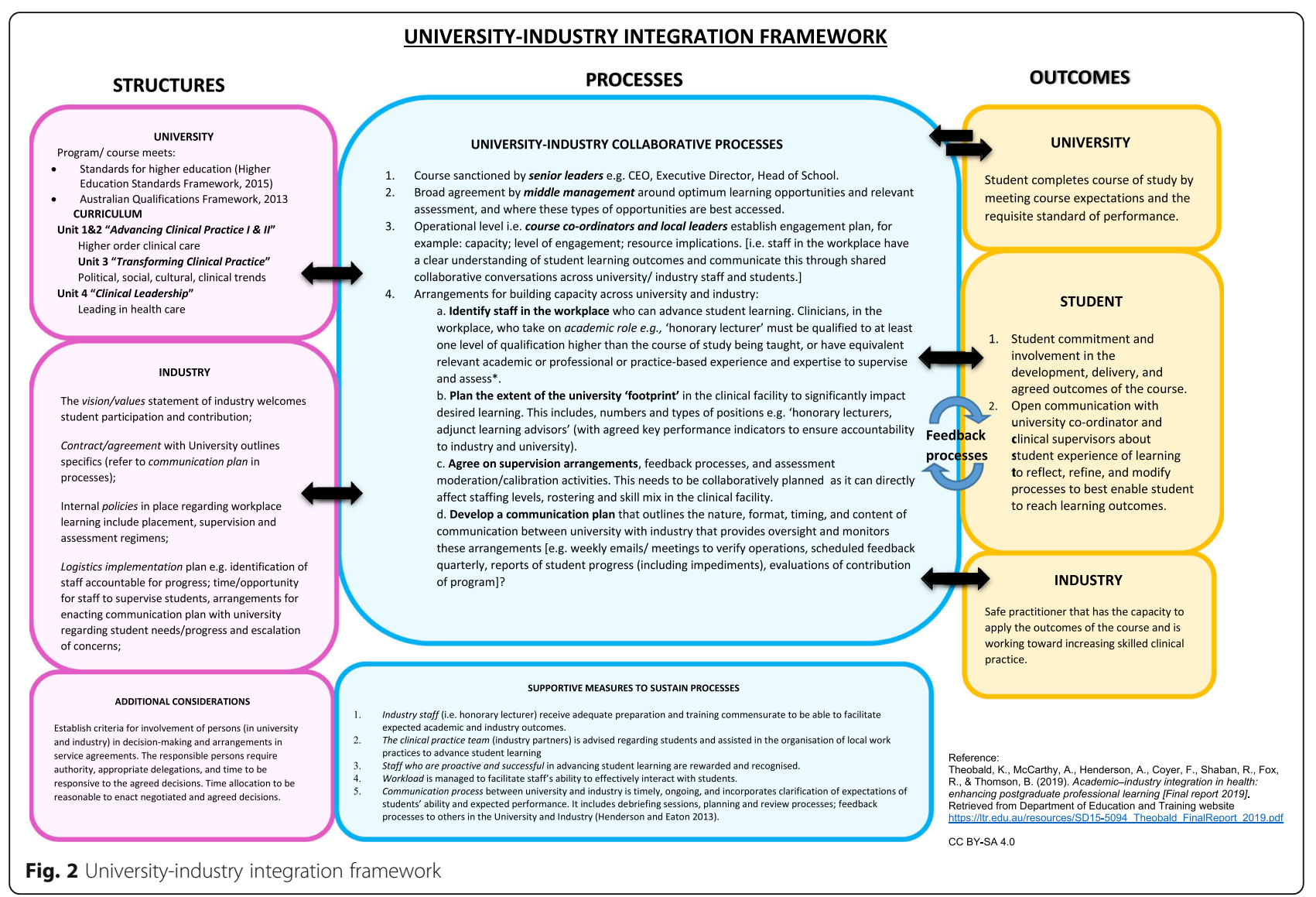

Table 1 Matrix 1: harmonisation of professional and regulatory imperatives for postgraduate coursework nursing education

\begin{tabular}{|c|c|c|c|c|}
\hline $\begin{array}{l}\text { Level of } \\
\text { nursing }\end{array}$ & $\begin{array}{l}\text { AQF } \\
\text { level }\end{array}$ & National nurse standard or reference & Curriculum content & Curriculum nature \\
\hline $\begin{array}{l}\text { Registered } \\
\text { nurse }\end{array}$ & 7 & NMBA Registered Nurse Standards for Practice 2016 [10] & NMBA-legislated educational requirements & $\begin{array}{l}\text { Competency-based } \\
\text { as per NMBA } \\
\text { standards }\end{array}$ \\
\hline $\begin{array}{l}\text { Domain- } \\
\text { specific } \\
\text { nurse }\end{array}$ & 8 & NMBA Registered Nurse Standards for Practice 2016 [10] & $\begin{array}{l}\text { - Specialty college or association standards } \\
\text { (where these exist) } \\
\text { - Actual and emergent imperatives in specialty } \\
\text { health care delivery articulated by industry } \\
\text { reference groups }\end{array}$ & $\begin{array}{l}\text { Competency-based } \\
\text { as per NMBA } \\
\text { Standards }\end{array}$ \\
\hline $\begin{array}{l}\text { Advanced } \\
\text { practice } \\
\text { nurse }\end{array}$ & 9 & $\begin{array}{l}\text { NMBA Fact Sheet on Advanced Practice Nursing } 2019 \\
\text { [1 1]; and Identifying advanced practice: A national } \\
\text { survey of a nursing workforce Gardner et al., } 2016 \text { [12] }\end{array}$ & $\begin{array}{l}\text { - Will vary slightly according to whether nurse } \\
\text { is classified as 'clinical', 'consultative' or } \\
\text { 'classical' [12] advanced practice nurse } \\
\text { - Actual and emergent imperatives in health } \\
\text { care delivery articulated by industry reference } \\
\text { groups }\end{array}$ & $\begin{array}{l}\text { Theory-based (no } \\
\text { NMBA standards } \\
\text { exist) }\end{array}$ \\
\hline $\begin{array}{l}\text { Nurse } \\
\text { practitioner }\end{array}$ & 9 & NMBA Nurse Practitioner Standards for Practice 2014 [13] & NMBA-legislated educational requirements & $\begin{array}{l}\text { Theory- and } \\
\text { competency-based } \\
\text { as per NMBA } \\
\text { standards }\end{array}$ \\
\hline
\end{tabular}

Reference: Theobald, K., McCarthy, A., Henderson, A., Coyer, F., Shaban, R., Fox, R., \& Thomson, B. (2019). Academic-industry integration in health: enhancing postgraduate professional learning [Final report 2019]. Retrieved from Department of Education and Training website https://tr.edu.au/resources/SD15-5094_ Theobald_FinalReport_2019.pdf. CC BY-SA 4.0 https://creativecommons.org/licenses/by-sa/4.0/ 
Table 2 Matrix 2: mutual expectations to ensure teaching and learning quality and employability, graduates in postgraduate nursing coursework

\begin{tabular}{ll}
\hline Guiding & Curricula are underpinned by: \\
principles & - Mutual understanding of the goal postgraduate \\
& attributes. The key question should always be: "What \\
& sort of postgraduate do we want to produce?" \\
- Clear articulation of mutual curriculum values via a & conceptual model of nursing practice, such as the \\
& Strong Model \\
- Equal industry and academic referencing & - Respectful relationships between industry and \\
& academe, which has mutual mentoring and capacity \\
& building processes embedded to establish a \\
& sustainable teaching and learning community of \\
& practice \\
- Distributed leadership with mutually-determined, well- & articulated, fit-for-purpose roles for each person. A \\
& 'consortium' approach is ideal. \\
- Industry engagement in academic activity that is \\
adequately resourced in human and material terms to \\
ensure robust curriculum development and delivery \\
• Mutual articulation and understanding of student, \\
organisational and professional needs
\end{tabular}

$\begin{aligned} & \text { Course } \\ & \text { development }\end{aligned}$
established; e.g.:
Who will be involved in the clinical learning
agenda (students, industry representatives,
academics, consumers), and how will this be
determined
Extent and mode of their involvement
Methods to identify and resolve clinical, academic
and regulatory issues determined
Articulation and actioning of enablers to
engagement
Articulation of and solution to barriers to
engagement
Timing and format of joint communications
How distributed leadership will be enacted

- Mutual understanding of entry and exit requirements

- Robust evidence

- Explicit relationships between, and integration of, all course content and strategies

- Viable inter-institutional methods of assuring learning and teaching standards

- Evaluation underpinned by mutually-relevant metrics

- Curricula that are jointly developed and delivered by health services and universities are informed by a viable, mutually-acceptable business model

- Accountability for implementing agreed actions is built in

- Articulation process between health service and university courses should be flexible and seamless for students, with clearly articulated processes.

\section{Course \\ delivery \\ outcomes}

Content

Target postgraduate capabilities as per Strong Model are articulated and woven through all aspects of course

\section{Contexts of} learning

Specialty college or association-specified content that is competency-driven (AQF Level 8) Driven by discrete context of practice and explicitly underpinned by theory as well as competency (AQF Level 9)

Build on resources health services and universities have already developed; e.g. advanced life support in university course assumes achievement of basic life support competency in hospital Community settings Policy settings Simulation lab Face-to-face (lectures, tutorials) Online (synchronous and asynchronous)

- Forward mapping: Developmental learning outcomes that take student from the known to the unknown (i.e. equivalent to knowledge $\rightarrow$ skills $\rightarrow$ application; or competence $\rightarrow$ capability) are scaffolded throughout the course, units and assessments

- Back mapping: The ideal course graduate is the starting point. Backward design begins with the objectives of the course-what students are expected to learn and be able to do on graduation; it then proceeds "backward" to create learning experiences and strategies to achieve those goals

- Openness to a 'pick and mix' or 'shopping cart' approach; that is, modular approach where all modules are focused on learning outcomes, but the mix of modules is adaptable to student needs

Teaching approaches

Scaffolded from information transmission, to concept acquisition (knowledge), to concept development (skills), to concept change (application)

All teaching strategies and

assessment processes scaffold developmental learning outcomes Interdisciplinary teaching Cross-specialisation teaching (e.g. emergency nurses teach physical assessment)

\section{Learning Assessment approaches principles}

Industry case study Clinical simulation Industry mentoring Industry placement Rotational placements Developing patient plans Self-directed learning Group learning Individual learning Remote simulation processes are statement on prepared. by clinicians,
Clinical competency assessments and consistent with the NMBA position assessing standards for registered nursing practice (2015); e.g., clinical competency assessments are performance-based and undertaken in the practice context by assessors who are appropriately clinically and academically

Clinical competencies should be assessed theoretical assessments by academics but all jointly decided on, depending on context. Flexibility in clinical competency

\section{Assessment types}

Competency assessment Practice audit Create policy and practice guideline Present inservice Classical essay Classical multichoice and short answer exams Portfolios of key competencies and capabilities Small or large thesis or project 
Table 2 Matrix 2: mutual expectations to ensure teaching and learning quality and employability, graduates in postgraduate nursing coursework (Continued)

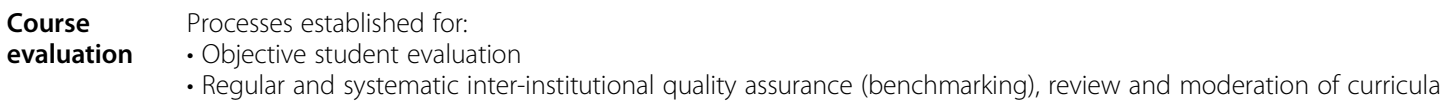

Reference: Theobald, K., McCarthy, A., Henderson, A., Coyer, F., Shaban, R., Fox, R., \& Thomson, B. (2019). Academic-industry integration in health: enhancing postgraduate professional learning [Final report 2019]. Retrieved from Department of Education and Training website https://tr.edu.au/resources/SD15-5094_ Theobald_FinalReport_2019.pdf. CC BY-SA 4.0 https://creativecommons.org/licenses/by-sa/4.0/

determined, fully-articulated, fit-for-purpose roles for each stakeholder, was finalised.

Data collection activities included evidence-based codesign techniques such as ice-breaking sessions, small and large group brainstorming, group generation of themes using post-it notes and buzz groups. With the agreement of participants, written outputs of group work, such as mind maps, were retained and intensive field noting of verbal outputs based on informal interviews was undertaken by a Chief Investigator during each workshop. Other research team members made field notes while facilitating break-out groups and also provided group-approved summaries of key points, which were included in the analysis. Due to the highly

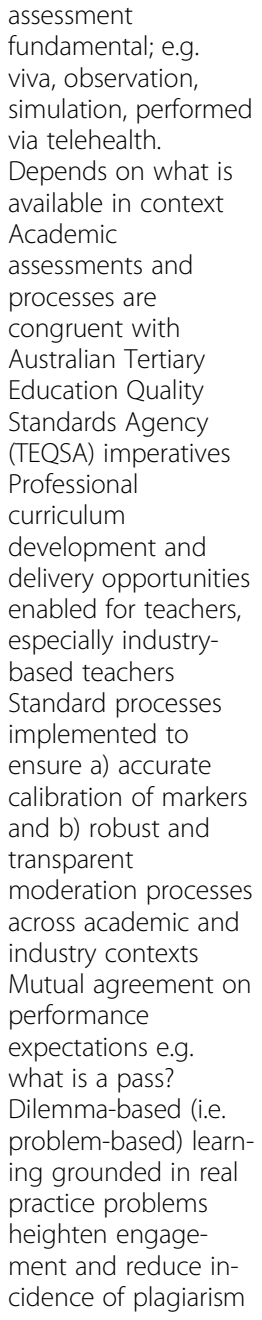

interactive nature of workshops and number of participants, it was not useful to audio-record the proceedings.

\section{Post-workshop}

Post-workshop emails were sent to all participants requesting feedback and input on workshop summaries, materials and outcomes, including questions with reference to the literature. Five current students provided feedback on materials that were developed from the three workshops between May and June 2017. Past students also contributed to Workshops 1 and 3. After the workshops, two focus groups (50 \& $60 \mathrm{~min}$ each) were conducted with five students from two different universities, who were enrolled as internal and external 
students. Two students met with one researcher individually for a 35 and 45-min interview. Comprehensive field notes were made by the Chief Investigator during focus groups and interviews. Feedback from students provided insight of role in curricula development, implementation and evaluation, as well as applicability of the graduate certificate example and university-industry framework.

\section{Data analysis}

The workshops, follow-up consultations, focus groups and interviews generated qualitative data. Analysis of these data was iterative, moving from initial codes to researcher-created ideas and the formation of themes. The analysis moved from descriptive to abstract analytical concepts and culminated in two main themes [14, 15]. The process was led by two experienced qualitative researchers and involved ongoing dialogue with all researchers with an awareness of testing validity through the interpretations generated [14].

\section{Results}

The number of participants able to attend all or part of each workshop was influenced by clinical demands at the time and ranged from nine (Workshop 3), to 16 (Workshop 2) and 21 (Workshop 1).

The data formed eight categories that fell within two main themes. These two themes are summarised in the two matrices presented in Tables 1 and 2. Matrix 1 [or theme 1] (Table 1) harmonises the first two categories: the mandatory factors that shape postgraduate nursing curricula in Australia and the need for a unifying model of nursing practice across educational contexts. Matrix 2 [theme 2] (Table 2) systematically articulates the remaining six categories. These cover the principles and processes that should be thought-out when developing and delivering emergency nursing curricula. These include good practice principles of professional learning; types of professional learning; stakeholder terms of engagement; scaffolding of teaching and learning; harnessing the diverse contexts of learning; and assuring course quality. The data were also drawn on to develop an interim framework (Fig. 2). The categorised data were also provided to participants for review and feedback.

The two matrices aligned the postgraduate emergency nursing education goals and curriculum development processes of the local health care service industry, national health care regulators and national higher education bodies, as well as the professional learning and credentialing needs of students and their employers. A robust thread running through both themes was the importance of work-integrated learning to prepare postgraduate students for practice. The culmination was mutual agreement of an operational framework to optimise learning of emergency nursing based on an academic-industry-student collaborative approach (Fig. 2) as well as the creation of a graduate certificate in emergency nursing curriculum exemplar. This led to establishment of principles to guide future curriculum development, implementation and evaluation.

Five guiding principles (Fig. 1) of curriculum development, implementation and evaluation were then established to inform the processes subsequently used in the study. Beneficial in the establishment, maintenance and development of a co-curricular distributed leadership partnership, the principles demarcate and represent the evolutionary steps involved in moving through design and creation phases to achieving capability with tangible outcomes and future direction. Emerging from curriculum development milestones and processes undertaken during the workshop series, the principles articulate the architecture of collaborative, linear and iterative scaffolded processes through which participants can transition while designing and constructing sustainable and suitable curricula. As such, a key outcome of Workshop 3 was the finalisation of a clinical-academic integration strategy and framework construction. This resulted out of a consortium approach of distributed leadership and jointly-determined, fully-articulated, fit-for-purpose roles for industry, university and student roles - the third principle.

However, to achieve capability, it was determined that respectful relationships between industry and academe must be maintained, and that affiliations that embedded joint mentoring and capacity building processes must be established. This would ensure a viable longer-term teaching and learning community of practice. To ensure robust development and delivery, successful postgraduate curriculum transformation also relies on health service provider engagement in appropriately-resourced academic activity. These were the final two guiding principles, delineated with the intention of providing future recommendations. The adoption of five guiding principles potentially supports the sustainable implementation of co-curricular partnerships.

Matrix 2 (Table 2) captures expectations of the various stakeholders with respect to learning and teaching quality and enhancing student employability. The participants considered it essential that all stakeholders understand and articulate the good practice principles of nursing curriculum development and delivery before they determine teaching and learning processes. Participant summaries generated through workshops are represented in Table 2 and Figs. 1 and 2.

Process issues were also important for participants, as summarised in Matrix 2. They encouraged stakeholders to formulate agreed terms of engagement from the outset. For example, explicit discussions occurred about 
who should be involved in the professional learning agenda, how to identify and resolve health service, university, credentialing and regulatory issues, articulation of enablers, barriers and solutions to engagement, the most desirable timing and format of joint communications, and how best to enact distributed leadership taking place before course development. It was also considered important to tease out technical issues, such as how best to scaffold learning. Participants further identified that workable cross-institutional ways of ensuring learning and teaching standards and undertaking mutual peer review and moderation were essential to ensure courses met student needs. While resolution of these issues was beyond the scope of this study, these notions certainly warrant further research as to how they might be achieved.

\section{Graduate certificate of emergency nursing curriculum exemplar}

In harmonisation with the principles and objectives that transpired through creation of a framework, an exemplar Graduate Certificate of Emergency Nursing was developed. Key facets were also delineated as part of the second matrix. It is positioned as a course outline that can be used by any health service or university, an instrument that guides the development of learning and teaching strategies and curriculum content [14].

\section{A fit-for-purpose university-industry integration framework}

An important issue identified during workshops was the need to harmonise regulatory and other imperatives, while ensuring that course content and level of learning are congruent with the student's target level of nursing practice. In essence, the course should overtly and systematically prepare the nurse for either specialty emergency practice, advanced emergency nursing practice or for a nurse practitioner position. Participants further identified that postgraduate education is often undertaken to enhance employability. Hence, successfullycompleted courses should readily help students to progress through the levels of practice embodied in the nursing career structure. Workshop consensus was that to ensure harmonisation and to assist career progression, a unifying model of nursing practice that accurately reflects the target practice profile and maps to the career pathway is needed. This would underpin all postgraduate courses, irrespective of whether they are offered by universities or health services. Subsequently, a university-industry integration framework (Fig. 2) was developed, to represent the structures, processes and outcomes required in developing and delivering postgraduate nursing courses that are co-created in university-industry service provider partnerships.

\section{Discussion}

The most important finding arising from this study was the overwhelming desire for industry to be involved in all aspects of university postgraduate emergency course development and for universities to likewise be involved in courses developed and delivered by industry (Fig. 2). Traditionally stakeholder involvement in course advisory committees provides a controlled environment for engagement, yet in this project, co-design enabled a more equal playing field of all stakeholder contributions. The emphasis all participants placed on mutual involvement was significant, but deliberations indicated that currently, it is not well-operationalised. This is despite the fact that tertiary education in Australia is regulated by the Tertiary Education Quality Standards Agency (TEQS A) [16] stipulate that universities engage regularly with course advisory committees comprising industry stakeholders to ensure the relevance and currency of their curricula. Similarly, health services often seek university advice to ensure the congruence of their professional development offerings with AQF Level 8 courses to provide a postgraduate articulation pathway for their emergency nursing students. Graduate Transition Programs offered in Queensland, Australia are good examples. These hospital-based programs deliver an entry to specialty program to newly-graduated/employed registered nurses, which can often be credited towards university study [7]. However, discussions during workshops clearly indicated that while both universities and hospitals do seek input from the other, this tends to occur when courses are already conceptualised and largely developed. In contrast, Henderson and Creedy [17] argue that the best student learning experiences occur when clinical content, context and teaching approaches are negotiated from the beginning of course development.

Consistent with the literature [18-21] the data indicated that it was important to have a range of professional learning experiences and related assessment methodologies (e.g., industry case studies, simulation, industry mentoring, industry placements) within curricula and adapted to context. Work-integrated learning and assessment for a rural emergency nurse, for example, might be made most relevant if metropolitan placements, or video-conferenced simulations, are embedded. As presented in Matrix 1, the educational value of learning-in-place warrants explicit acknowledgment within university postgraduate nursing curricula [12]; however, workplaces should also understand both what students bring to work-integrated learning placements and what they need from the workplace to maximise their learning [22].

The risk of universities providing sub-standard learning experiences for nurses without deep industry 
engagement was also highlighted in this study. This is corroborated by Australian research in the higher degree context, which clearly demonstrated the ill-preparedness of graduate and postgraduate students for the "world of work' [20, 23]. Substantial evidence from multiple practice disciplines further indicates that deep learning can only occur if industry and disciplinary bodies are explicitly engaged in university course development and delivery [6]. Mutually determined work-integrated learning approaches appear to be the best way to enable authentic learning environments [6, 20,24]. Hence, Matrix 2 is anchored in principles such as ensuring industry referencing throughout course development and delivery; initiating and sustaining collegial relationships; properly resourcing industry involvement in curricula; fully understanding the students' learning needs by involving them in course development; and ensuring that curriculum currency is maintained.

The five guiding principles created from this study are starting points for those looking to co-design and implement a postgraduate curriculum in partnership. Our experiences of industry and academe working respectfully and collectively culminated in shared outcomes grounded in these principles. Further, the value that all participants placed on integrating workplace-based learning into university courses targeting domainspecific and advanced practice nurses [11], as well as nurse practitioners [13], warrants consideration. Sociocultural theories of workplace learning propose that optimal learning outcomes are the result of students' active participation in clinical activities during their study, coupled with their 'real-life' learning interactions with the complex and dynamic clinical work environment $[18,22,25]$. Hence, alignment of the industry-academic agenda through well-designed work-integrated learning and assessment experiences increases the relevance of postgraduate courses in emergency nursing (Table 2).

The co-designed Graduate Certificate of Emergency Nursing exemplar developed during this study encompasses the requirements of industry and aims to provide students with quality learning and useable course outcomes. It embraces the imperatives and mutual goals of both industry and universities, while harmonising diverse pedagogical approaches. Devised as a means of strengthening industry-university collaboration, it serves to bridge the current gap between practical capabilities and theoretical scaffolding of learning (reflective of AQF compliance), while meeting the regulatory requirements of the Nursing and Midwifery Board of Australia [10, 11].

\section{Implications}

This study has highlighted the potential of an industryacademic agenda increasing the relevance of postgraduate specialist courses in health, reinforcing the connection between industry and higher education to promote postgraduate learning and employability. Figure 2 provides a unique future blueprint for employability skills to build more collaborative partnerships between employers, industry, higher education and professional bodies in health. In the future, we hope to test the Framework formally, along with its emergency nursing exemplar. The aim is to ensure the transparency of the Framework, promote sustainability of the embedded principles, develop and operationalise joint governance processes and support continuing development of such educational partnerships.

\section{Limitations of the study}

We acknowledge the lack of generalisability of this study's findings, namely that the findings are contextspecific to health services and universities involved. However, given the depth of participants' background, from clinical care to professional organisation and academic representatives, we suggest that our framework is considered, it can be adapted to other postgraduate nursing contexts.

\section{Conclusions}

This study presented a joint exploration of strategies to design nursing curricula, with the objective of producing work-ready postgraduates who benefit from a thoughtful blend of clinical and university learning experiences. We also illuminated the role of local hospitals and universities in preparing registered nurses for specialist employment and explored how to embed these ideas within curricula using the exemplar of postgraduate emergency nursing. Consensus from the workshops indicates that in the ideal scenario, the framework could be used widely by local health services and universities to guide their joint development of courses, where work-integrated university-level teaching and learning are embedded. The strategies and exemplars developed in this study offer guidance for any professional education provider. The framework exemplifies a spirit of consultation and collaboration, valuing student voice that could usefully guide future joint curriculum development and delivery in other postgraduate nursing specialities.

\section{Abbreviations \\ AQF: Australian Qualifications Framework; HEP: Higher education providers; CENA: College of Emergency Nursing Australasia; TEQSA: Tertiary Education Quality Standards Agency \\ Acknowledgements \\ The authors wish to thank Professor Ramon Shaban (early research contribution), Mr. Ben McGarry and Ms. Kerri Gillespie (Research Assistants) and the Office of Learning and Teaching (OLT) Grants, Australian Government, for Seed Grant funding.}

\section{Authors' contributions}

All authors have made substantial contributions to the following: Conception and design of the study (KT, AMc, FC, AH, RF, BT). Acquisition of data (KT, $A M C, F C, A H, R F, B T)$. Analysis and interpretation of data (KT, AMC). Drafting 
the article or revising it critically for important intellectual content (KT, FC, AMc, $A H)$. Final approval of the version to be submitted (KT, FC, AMc, AH, RF, BT).

\section{Funding}

The work was supported by the Office of Learning and Teaching (OLT)

Grants, Australian Government, for Seed Grant funding: (SD15-5094).

\section{Availability of data and materials}

The datasets used and/or analysed during the current study are available from the corresponding author on reasonable request.

\section{Declarations}

\section{Ethics approval and consent to participate}

The study was approved by Queensland University of Technology Human Research Ethics Committee (UREC/1600000154) and Griffith University Human Research Ethics Committee (2016/227). Written consent was gained from all participants prior to involvement.

\section{Consent for publication}

Not applicable.

\section{Competing interests}

The authors declare that they have no competing interests.

\section{Author details}

${ }^{1}$ School of Nursing, Faculty of Health, Queensland University of Technology, GPO Box 2434, Brisbane, Queensland 4000, Australia. ${ }^{2}$ Centre for Health Care Transformation, Q Block, 60 Musk Avenue, Kelvin Grove, Queensland 4059, Australia. ${ }^{3}$ Royal Brisbane and Women's Hospital, Herston, Queensland 4029, Australia. ${ }^{4}$ School of Nursing, Midwifery and Social Sciences, Central Queensland University, Brisbane, Queensland 4000, Australia. ${ }^{5}$ Princess Alexandra Hospital, 199 Ipswich Road, Woolloongabba, Queensland 4102, Australia. ${ }^{6}$ Metro North Hospital and Health Service, Herston, Queensland 4029, Australia. ${ }^{7}$ School of Nursing, Social Work and Midwifery, University of Queensland, St Lucia, Queensland 4072, Australia. ${ }^{8}$ Mater Health Services, Raymond Terrace, South Brisbane, Queensland 4101, Australia.

\section{Received: 8 October 2020 Accepted: 2 March 2021}

Published online: 12 March 2021

\section{References}

1. Morphet J, Kent B, Plummer V, Considine J. The effect of transition to specialty practice programs on Australian emergency nurses' professional development, recruitment and retention. AENJ. 2015. https://doi.org/10.101 6/j.aenj.2015.08.001.

2. Australian Qualifications Framework Council, editor. Australian qualifications framework. 2nd ed: Australian Qualifications Framework Council; 2013. www.agf.edu.au. Accessed 7 Feb 2021

3. Dzau VJ, Cho A, Ellaissi W, Yoediono Z, Sangvai D, Shah B, Zaas D, Udayakumar K. Transforming academic health centres for an uncertain future. N Engl J Med. 2013. https://doi.org/10.1056/NEJMp1302374.

4. Find A Masters. Masters study in the USA - a guide for 2019. https://www. findamasters.com/study-abroad/america/masters-study-in-usa.aspx. Accessed 7 Feb 2021.

5. IDP Connect Limited. Postgraduate Nursing. 2019. https://www.postgradua tesearch.com/pgs/search?course=nursing. Accessed 7 Feb 2021.

6. Papadopolous A, Taylor T, Fallshaw E, Zanko M. Engaging industry: embedding professional learning in the business curriculum. 2011; https:// ro.uow.edu.au/cgi/viewcontent.cgi?referer=https://www.google.com/ \&httpsredir=1\&article=1782\&context=buspapers. Accessed 7 Feb 2021

7. Juers A, Wheeler M, Pascoe H, Gregory N, Steers C. Transition to intensive care nusring: a state-wide, workplace centred program - 12 years on. Aust Crit Care. 2012. https://doi.org/10.1016/j.aucc.2011.09.001.

8. Sanders EBN, Stappers PJ. Co-creation and the new landscapes of design. CoDesign. 2008. https://doi.org/10.1080/15710880701875068.

9. Ogrin R, Viswanathan R, Aylen T, Wallace F, Scott J, Kumar D. Co-design of an evidence-based health education diabetes foot app to prevent serious foot complications: a feasability study. Pract Diabetes Int. 2018. https://doi. org/10.1002/pdi.2197.
10. Nursing and Midwifery Board of Australia. Registered nurse standards for practice. 2016. https://www.nursingmidwiferyboard.gov.au/codes-guidelinesstatements/professional-standards/registered-nurse-standards-for-practice.a spx. Accessed 7 Feb 2021.

11. Nursing and Midwifery Board of Australia. Fact sheet: advanced nursing practice and specialty areas within nursing. 2019. https://www. nursingmidwiferyboard.gov.au/Codes-Guidelines-Statements/FAQ/fact-sheet-a dvanced-nursing-practice-and-specialty-areas.aspx. Accessed 7 Feb 2021

12. Gardner G, Duffield C, Doubrovsky A, Adams M. Identifying advanced practice: a national survey of a nursing workforce. Int J Nurs Stud. 2016;55 https://doi.org/10.1016/j.jinurstu.2015.12.001.

13. Nursing and Midwifery Board of Australia. Nurse practitioner standards for practice. 2014. https://www.nursingmidwiferyboard.gov.au/CodesGuidelines-Statements/Professional-standards/nurse-practitioner-standardsof-practice.aspx. Accessed 7 Feb 2021

14. Theobald K, McCarthy A, Henderson A, Coyer F, Shaban R, Fox R, Thomson $B$. Academic-industry integration in health: enhancing postgraduate professional learning: Learning and Teaching Repository website; 2019. https://tr.edu.au/resources/SD15-5094_Theobald_FinalReport_2019.pdf. Accessed 7 Feb 2021

15. Rapley T. Some pragmatics of qualitative data analysis. In: Silverman D, editor. Qualitative research. 4th ed. London: Sage Publications Limited; 2016. p. 331-45.

16. Tertiary Education Quality and Standards Agency. Higher education standards framework 2015. https://www.teqsa.gov.au/higher-education-sta ndards-framework-2015. Accessed 7 Feb 2021

17. Henderson A, Creedy D. Leading engagement of academic and clinical communities for learning. Sydney: Australian Learning and Teaching Council; 2008

18. Govaerts M, van der Vleuten CPM. Validity in work-based assessment: expanding our horizons. Med Educ. 2013. https://doi.org/10.1111/medu.12289.

19. Kinsella D, Fry M, Zecchin A. Motivational factors influencing nurses to undertake postgraduate hospital-based education. Nurse Educ Pract. 2018. https://doi.org/10.1016/j.nepr.2018.04.011.

20. Lin YY, Lee YH, Chang SC, Lee DC, Lu KY, Hung YM, Chang YP. Individual resilience, intention to stay, and work frustration among postgraduate twoyear programme nurses. Collegian. 2018. https://doi.org/10.1016/j.colegn.2 018.12.001.

21. Scott G. 'Right' program level outcomes first. 2019; http://flipcurric.edu.au/a bout-143/overview-of-the-six-keys/right-program-level-outcomes. Accessed 7 Feb 2021.

22. Billett $\mathrm{S}$. Developing agentic professionals through practice-based pedagogies. 2007. https://altf.org/fellowships/developing-agenticprofessionals-through-practice-based-pedagogies/. Accessed 7 Feb 2021

23. Cumming J, Kiley M, Thomas M, Hort L, Pike M, Evans E, Main A. Research graduate skills project. Sydney: Australian Learning and Teaching Council; 2009.

24. Henderson A, Trede F. Strengthening attainment of student learning outcomes during work integrated learning: a collaborative governance framework across academic, industry and students. APJCE. 2017;18(1):73-80.

25. Russell K, Coventry T. Innovations in postgraduate work integrated learning within the perioperative nursing environment: a Western Australian experience. JPN. 2016;29(4):15-9.

\section{Publisher's Note}

Springer Nature remains neutral with regard to jurisdictional claims in published maps and institutional affiliations.

Ready to submit your research? Choose BMC and benefit from:

- fast, convenient online submission

- thorough peer review by experienced researchers in your field

- rapid publication on acceptance

- support for research data, including large and complex data types

- gold Open Access which fosters wider collaboration and increased citations

- maximum visibility for your research: over $100 \mathrm{M}$ website views per year

At $\mathrm{BMC}$, research is always in progress.

Learn more biomedcentral.com/submission 